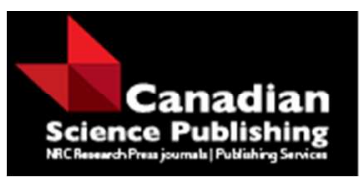

Canadian Journal of Forest Research Revue canadienne de recherche forestière

\title{
Exotic earthworm (Oligochaeta: Lumbricidae) assemblages on a landscape-scale in central Canadian woodlands: Importance of region and vegetation type
}

\begin{tabular}{|r|l|}
\hline Journal: & Canadian Journal of Forest Research \\
\hline Manuscript ID & cjfr-2016-0337.R1 \\
\hline Manuscript Type: & Article \\
\hline Date Submitted by the Author: & 18 -Jan-2017 \\
\hline Complete List of Authors: & $\begin{array}{l}\text { Choi, Amy; University of Toronto, Faculty of Forestry } \\
\text { Sackett, Tara; University of Toronto, Faculty of Forestry } \\
\text { Smith, Sandy; University of Toronto } \\
\text { Bellocq, M.; Universidad de Buenos Aires Departamento de Ecologia } \\
\text { Genetica y Evolucion, Facultad Ciencias Exactas y Naturales }\end{array}$ \\
\hline Keyword: & $\begin{array}{l}\text { Earthworm communities, Functional groups, Invasive species, Land use, } \\
\text { Lumbricidae }\end{array}$ \\
\hline &
\end{tabular}

\section{SCHOLARONEm \\ Manuscripts}


1 Exotic earthworm (Oligochaeta: Lumbricidae) assemblages on a landscape-scale in central

2 Canadian woodlands: Importance of region and vegetation type

5 Amy Choi, Tara E. Sackett, Sandy M. Smith, and M. Isabel Bellocq ${ }^{1}$

6

7

8

9

10

11

12

13

14 University of Toronto, Faculty of Forestry, 33 Willcocks Street, Toronto, Ontario, Canada, M5S

$15 \quad 3 \mathrm{~B} 3$

16 ' Departamento de Ecología, Genética y Evolución, Facultad Ciencias Exactas y Naturales,

17 Universidad de Buenos Aires, and IEGEBA, CONICET

18 amy.cw.choi@gmail.com, tara.sackett@utoronto.ca, s.smith.a@utoronto.ca,

19 bellocq@ege.fcen.uba.ar 
20 Abstract: A growing understanding about the impacts of earthworms (Oligochaeta:

21 Lumbricidae) on ecosystem processes and forest restoration necessitates an examination of their

22 role in Canadian forests where they have become invasive. Little is known about the landscape

23 scale responses of earthworm populations to different regional characteristics and vegetation

24 types within Canada's central woodlands. We examined the regional variation of earthworm

25 species richness, biomass, and assemblage composition across a range of four municipal regions

26 (from south to north: Halton, Wellington, York, and Simcoe) and four habitat types (deciduous

27 forest, mixed forest, tree plantation, and meadow) with varying soil characteristics in woodlands

28 of south-central Ontario, Canada. In general, earthworm communities differed by region but not

29 by habitat type. The most southern regions supported the highest earthworm species richness,

30 biomass (i.e. Lumbricus and Octolasion), and density, and this was associated with a south-north

31 gradient in soil characteristics. Assemblage composition differed by region but not by habitat

32 type. The observed south-north gradient suggests an underlying effect of invasion spread

33 associated with human settlement and density. Our results provide baseline information about

34 earthworm communities in south-central Ontario forests, and will enable managers to plan for

35 the increasing role of earthworms in Canada's future forests.

38 Key words: earthworm communities, functional groups, invasive species, land use, Lumbricidae 


\section{Introduction}

The southern extent of the last Wisconsonian glaciation eliminated most native

44 earthworm species from Canada and the northern United States (Callaham et al. 2006, Addison

45 2009). Exotic earthworm species (Oligochaeta: Lumbricidae) were introduced during the late

461800 s, presumably through the release of contaminated soil in ship ballasts from Europe

47 (Reynolds 1977; Tiunov et al. 2006); they are now widely distributed in select locations across

48 much of North America (Gates 1982; Reynolds 1994), where they re-engineer soil and site

49 characteristics. Because soils, vegetation, and ecosystem processes in Canadian temperate forests

50 have developed in the absence of earthworms following recent glacial recession, such invasions

51 cause major shifts in ecosystem functioning and services, impacting forest floor structure, soil

52 biogeochemistry, and faunal and plant community composition (e.g., Alban and Berry 1994;

53 Hale et al. 2005; Bohlen et al. 2004; Migge-Kleian et al. 2006; Holdworth et al. 2007a and b;

54 Costello and Lamberti 2009; Szlavecz et al. 2011; Crumsey et al. 2013; Sackett et al. 2013,

55 Craven et al. in press).

It is now well documented that earthworm invasion results in significant changes to

57 nutrient dynamics and soil structure in temperate forests (e.g., Hale et al. 2005; Sackett et al.

58 2013). For example, the feeding habits of Lumbricus terrestris have been shown to increase the

59 immobilization of nutrients leading to nitrification and leaching and an overall decrease in

60 nutrient availability (Hale et al. 2005). Earthworms may also shift the soil decomposer

61 community from one dominated by fungi and their interactions to one dominated by bacteria or

62 fungi antagonistic to decomposing fungi, again changing the rate of nutrient cycling and

63 decomposition (Bohlen et al. 2004; Jayasinghe and Parkinson 2009; Ewing et al. 2015). 
64 Changes caused by the invasion of earthworms are also known to result in a loss of carbon (C)

65 storage due to increased respiration and microbial activity; however, in the long term,

66 earthworms may stabilize soil carbon by incorporating greater amounts of the litter layer into

67 their casts and stable aggregates (Bohlen et al. 2004).

The pattern of invasion and impact of earthworms is much dependent on land use history,

69 soil type, and functional traits of the invading species, amongst other factors (Frelich et al. 2006).

70 Whether a species is classified as epigeic, endogeic or anecic will determine the potential change

71 in soil characteristics. In general, as species richness increases, the thickness of the litter and duff

72 layer of the soil decreases (Gundale et al. 2005). McLean and Parkinson (1997) found that

73 epigeic species had effects on organic matter distribution and soil structure. Variation in the

74 effects of these functional groups are expected due to their differential impact on the litter 'LFH'

75 layers, where ' $\mathrm{L}$ ' is the top organic horizon composed of accumulating leaves and twigs and still

76 easily recognized, ' $F$ ' is the layer of partially decomposed organic matter with a sometimes matt-

77 like appearance due to fungal hyphae and decaying litter, and ' $\mathrm{H}$ ' is the lowest organic horizon

78 in which the original organic structures cannot be recognized and have been converted to humic

79 material (Denholm et al. 1993; Soil Classification Working Group 1998). Epigeic species mix

80 and consume the ' $\mathrm{FH}$ ' layers, while the upper litter layer (L) remains intact (McLean and

81 Parkinson 1997; Hale et al. 2005). Endogeic and anecic species move deeper into the soil layers,

82 mixing the upper $25-30 \mathrm{~cm}$ of the mineral soil horizons ( $\mathrm{B}$ or $\mathrm{C}$ ) and converting the undisturbed

83 LFH and thin A horizon characteristic of native soils to a mull soil more similar to previously-

84 tilled agricultural soil (Frelich et al. 2006), and in turn impacting water infiltration (Capowiez et

85 al. 2014). 
Understanding the biogeographic patterns of invasive species as they colonize new

87 regions will help predict patterns of spread and the relative vulnerability of particular regions and ecosystems. At the landscape scale, the distribution of earthworms appears to be dependent on

89 habitat suitability ( $\mathrm{pH}$ and litter quality), climatic conditions (temperature and moisture), human

90 activity, and land use practices (Tiunov et al. 2006). Among habitat types, earthworm abundance

91 and species richness are generally the highest in deciduous forests and the lowest in old

92 meadows and coniferous forests (Smith et al. 2008). In some cases, the dominant tree species

93 may be important; for example, earthworms occurred less frequently in forests dominated by

94 American beech (Fagus grandifolia) and hemlock (Tsuga canadensis) than in other hardwoods

95 (Suárez et al. 2006b). In areas where forests are transitioning from southern deciduous species to

96 northern coniferous species, earthworm invasion may progress more slowly due to either

97 combined or individual effects of a decrease in litter quality (changes in tree species

98 composition), decrease in soil $\mathrm{pH}$, or decrease in temperature along a latitudinal gradient

99 (Addison 2009). Studies in Europe have shown earthworm distribution at the landscape level to

100 be dependent on climatic conditions, habitat suitability ( $\mathrm{pH}$ and litter quality), and human

101 activity and land use practices (Tiunov et. al. 2006).

102

Little is known about the distribution, impact or drivers of earthworm expansion into

103 central Canadian forests. Here, we conduct a landscape-scale study to compare earthworm

104 communities in different regions and habitat types in central Canadian woodlands. Specifically,

105 we examine the regional variation in earthworm community attributes (species richness, density,

106 biomass, composition) across a range of municipal counties and habitat types in south-central

107 Ontario, and identify habitat characteristics associated with attributes of earthworm communities.

108 We predict that southern regional jurisdictions will have greater earthworm abundance and 
109 species richness, especially for Lumbricus and epigeic species, than the northern regions, due to

110 the history of European settlement in this region. We also expected to find similar earthworm

111 species among similar habitat types due to the local biotic and abiotic conditions associated with

112 each, and higher biomass in deciduous forests than in other habitat types (Smith et al. 2008).

\section{Methods}

\section{Study design}

To analyze whether earthworm communities differed between regions and habitat type,

117 we selected four regional municipalities distributed along a $\sim 125 \mathrm{~km}$ transect in the south-north

118 direction of south-central Ontario: Simcoe County, York Region, Wellington County, and Halton

119 Region (Fig. 1; Table 1). These regions encompass the northern edge of the Carolinian forest

120 ecotone (Halton) as well as the Great-Lakes-St. Lawrence forest ecotone (Wellington, York, and

121 Simcoe) (NRCan 2012). We included four habitat types: deciduous forest, mixed forest, tree

122 plantation, and meadow. Within each of the four regions, two subsamples (sites) of each habitat

123 type were selected (with the exception of Halton Region where only one suitable meadow site

124 could be found) for a total of eight (seven in Halton) sites per region (total sites=31) (Fig. 1).

125 Sites were selected of similar age, history, and estimated recreational use wherever possible in

126 order to decrease variation (Table 2).

At each site, five plots $(10 \mathrm{~m} \times 10 \mathrm{~m})$ were sampled for earthworms, soils, and vegetation

128 during September-October, for a total of 155 plots. The plots were systematically selected

129 without preconceived bias at 30-50 m towards the interior of the forest but within $100 \mathrm{~m}$ from 
130 any road or trail. This approach to sampling was used in order to account for the degree of

131 uncertainty about differential invasion in each region and the potential for correlation between

132 earthworm abundance and proximity to roads (Cameron et al. 2007; Sackett et al. 2012).

133 Sampling was done at least $50 \mathrm{~m}$ away from a forest edge in order to ensure interior habitat.

134 Each plot was sampled once.

\section{Study area and site description}

The four study regions were similar in topography and representative of their respective

138 forest ecozones. Predominant tree species in the seven northern Carolinian forest sites included

139 American beech, maples (Acer spp.), black walnut (Juglans nigra), hickories (Carya spp.), and

140 oaks (Quercus spp.), while the 24 sites in the Great Lakes-St. Lawrence forest were

141 characterized by a greater percentage of conifers, such as red pine (Pinus resinosa), eastern white

142 pine (Pinus strobus), and eastern hemlock (Tsuga canadensis), as well as by yellow birch (Betula

143 alleghaniensis), maples, and oaks. The soils were variable among the regions, with podzolic soils

144 generally found in the north, andgleysols, luvisols, and brunisols in the south (Table 1). Average

145 annual precipitation and temperature was similar between the four regions, and all sites are

146 below $400 \mathrm{~m}$ in altitude.

All meadow and plantation sites we selected were historically used for agriculture, with

148 the exception of the two plantation sites in York region where there was no record of use for the

149 cleared land prior to the plantation; agricultural use was likely in this case too, considering the

150 historical patterns of cleared land across southern Ontario (Table 2). The deciduous and mixed

151 forest sites in the two southerly regions, Halton and Wellington, were also historically used for 
152 agriculture, with the exception of one mixed forest site in Halton, which had always remained as

153 forest. The deciduous and mixed forest sites in the two northern regions, York and Simcoe, had

154 never been cleared, and had no agricultural record. Forest management activities in these regions

155 are presently overseen by their respective regional foresters, with the exception of Wellington

156 County, where management is conducted by the City of Guelph and the Grand River

157 Conservation Authority. These forested areas are currently open to the public for a range of

158 recreational activities, including hiking, horseback riding, and cycling.

160 Habitat types

We defined the four habitat types based on the following criteria: (a) Deciduous Forest,

162 dominated by deciduous species such as sugar maple (Acer saccharum) or ash (Fraxinus spp)

163 comprising more than $50 \%$ of the total tree cover, and with only a minor component of

164 coniferous species, if any; (b) Mixed Forest, with more than 25\% of the total canopy cover

165 consisting of coniferous species such as hemlock, and usually having a higher diversity of tree

166 species than deciduous forests; (c) Plantation Forest, originally planted (usually in rows) as a

167 monoculture of one or a few conifer species such as white pine, red pine or white spruce

168 (Piceaglauca); and (d) Meadow, an area with less than 25\% cover of tree and shrub species,

169 composed largely of grasses and forbs such as goldenrods (Solidago spp.), and not actively

170 maintained for agricultural use (Lee et al. 1998) (Table 2). 


\section{Earthworm sampling and identification}

173

174 apart, in each of the 155 plots. Specimens were extracted using a mustard powder

175 (allylisothiocyanate) solution at a concentration of approximately $100 \mathrm{mg} \mathrm{l}^{-1}$ AITC (Zaborski 2003, Coja et al. 2008), appropriate for the range of soil types sampled here (Lawrence and collected and killed in a solution of 70\% isopropyl alcohol and water (Hale et al. 2008).

181 Specimens collected from the three quadrats were pooled by plot and then by site (5 plots per 182 site). Earthworms were fixed using a $10 \%$ formalin solution for $24 \mathrm{~h}$, and then put back into $70 \%$ 183 isopropyl alcohol for preservation.

Preserved earthworms were separated into three age classes based on clitellum

185 development; 1) juveniles (lacking clitellum), 2) adults (clitellate), and 3) pre-/post- clitellate 186 adults (clitellum not fully developed or clitellum absent but scar visible, respectively) (Reynolds 187 1977). Adult earthworms were then identified to species using Reynolds' (1977) key, counted, 188 and recorded. Juveniles could only be recorded to genus, unless the species were Dendrobaena 189 octaedra or Dendrodrilus rubidus, in which case they could be identified to species even as 190 juveniles. Octolasion juveniles and adults were grouped for analyses even though their juveniles 191 could not be confidently identified to species because only $O$. tyrtaeum adults were found.

192 Earthworms were weighed to $\pm 0.001 \mathrm{~g}$, grouped by genus, with the exception of $D$. octaedra and 193 D. rubidus, since they could be identified to species as juveniles. 
195 Vegetation sampling

Tree species composition, size class distribution, and basal area were assessed using a

197 standard stand analysis field sheet (Ontario Ministry of Natural Resources 2004) and a BAF2

198 prism at each of the 155 plots. Trees were divided into four size classes by diameter at breast

199 height (dbh); polewood $(10-25 \mathrm{~cm})$, small $(26-36 \mathrm{~cm})$, medium $(38-48 \mathrm{~cm})$, and large $(>50 \mathrm{~cm})$.

200 Values obtained from the five plots were pooled for each variable to characterize the site.

201 Presence of understory shrub and herbaceous species were recorded for all plant species

202 observed within the $10 \times 10-\mathrm{m}$ plots. The presence and species of tree seedlings were also

203 determined and included in the analysis. In Meadow plots, only forb species were recorded.

204 Values from the five plots were pooled for each site. To determine the approximate stand age

205 and management history, we consulted the forest managers in each region. A record of previous

206 harvesting practices and land uses was maintained for all regions.

208 Soil sampling and analysis

209 Approximately $10 \mathrm{~cm}^{3}$ of soil was collected from the top $10 \mathrm{~cm}$ of each plot, pooled by

210 site (5 plots per site), and analyzed for gravimetric soil moisture content, organic matter, texture,

$211 \mathrm{pH}$, and bulk density. Organic matter was measured through loss of ignition at $500^{\circ} \mathrm{C}$ for $4 \mathrm{~h}$;

212 initial tests for calcareousness using $10 \% \mathrm{HCl}$ determined that most of the soils were non- to

213 weakly calcareous (Denholm et al. 1993). Soil texture was measured using an adapted pipette

214 method (Kroetsch and Wang 2008), that measures sedimentation rates of sand (50 $\mu \mathrm{m}-2 \mathrm{~mm})$, 
215 silt $(2-50 \mu \mathrm{m})$, and clay $(0-2 \mu \mathrm{m})$ based on Stoke's law. Soil pH was measured from a well-

216 mixed slurry of $10 \mathrm{~g}$ of fresh soil and $40 \mathrm{~mL}$ of distilled water (Hendershot et al. 2008).A

217 separate soil sample was taken from the top $10 \mathrm{~cm}$ of soil of each plot using a metal ring of fixed

218 dimensions $(7.6 \mathrm{~cm} \mathrm{D} \mathrm{x} 4.4 \mathrm{~cm} \mathrm{H})$ and thus, a fixed volume $\left(199.7 \mathrm{~cm}^{3}\right)$ to determine bulk

219 density.

\section{$220 \quad$ Statistical analyses}

221 For statistical analysis, earthworm data from the two habitat subsamples per region were

222 pooled, and environmental data (soil and vegetation data) were averaged over the two habitat

223 subsamples per region. We decided to pool data rather than analyze subsample data in nested

224 analyses due to the high dissimilarity in earthworm biomass between many subsample pairs. This

225 high earthworm spatial heterogeneity on a local scale is not unusual based on repeated sampling

226 in other sites across this region of southern Ontario (T. Sackett, pers.obs.).

227 We compared the biomass of earthworms among habitat types and regions, and

228 considered both total biomass and biomass of earthworm genera for all samples where there were

229 more than two observations (Aporrectodea, Dendrobaena, Lumbricus, and Octolasion).

230 Differences in total earthworm biomass among habitat types and regions was tested using a

231 general linear model (function $1 \mathrm{~m}$ in $\mathrm{R}$ ); earthworm biomasses were $(\log +1)$ transformed before

232 analysis to achieve normality of residuals and homogenous variances. For each separate

233 earthworm genus, the error residuals and variances could not meet model assumptions even after

234 transformation. Therefore, we used a permutation (i.e. randomization) test to detect non-random

235 patterns of earthworm biomass with habitat and regions. For each genus, we randomized the

236 biomass data over all cells (habitat and region) and calculated the F-statistic for habitat and 
237 region effects using the $1 \mathrm{~m}$ function. We repeated this for 5000 iterations, creating a random

238 distribution of F-statistics for these data. We then compared our actual F-statistic with this

239 distribution to find the probability that the actual statistic was obtained from the random

240 distribution.

Non-metric multidimensional scaling (NMDS) was used to visually explore differences

242 in earthworm community composition among sites, after which, we used permutational

243 multivariate analysis of variance (pMANOVA) to test for differences in earthworm assemblage

244 composition among habitats and regions (Anderson 2001; McArdle and Anderson 2001). This

245 analysis is a non-parametric analysis of variance of distance matrices among groups. If any

246 factors in the overall pMANOVAmodel were significant, we performed pairwise tests. For both

247 the ordination and pMANOVA, we included only those earthworms identified to species (i.e.,

248 specimens only identified to genus were eliminated for the analysis), and also removed species

249 where less than five individuals were collected (D. rubidus, A. trapezoides) in order to reduce the

250 effect of these rare species on the analysis. Sites where no earthworms were identified to species

251 were also removed; this included the Plantation Forests in the Wellington region, and all

252 Meadow sites because only one of the seven Meadow sites had individuals identified to species.

253 For the remaining sites, we pooled the data from the five collections per sub-sample and two

254 sub-samples per habitat to yield 11 samples in the data set.

For the NMDS, we used a scree plot of dimensions versus stress to choose the number of

256 dimensions for the ordination ( 2 dimensions were adequate).The metaMDS function from the $\mathrm{R}$

257 package $\{$ vegan $\}$ was then used to perform the NMDS of species composition among sites,

258 building a Bray-Curtis distance matrix. We were particularly interested in exploring whether any

259 measured environmental or geographical (i.e., latitude) variables were correlated with 
260 differences in species composition among the sites, as represented in the NMDS configuration.

261 To evaluate this, we used the envfit function from the \{vegan package to test the strength and

262 direction of the relationship between the environmental variables with the NMDS sample

263 coordinates. Values from environmental variables were log-transformed before overlaying

264 because envfit assumes a linear relationship between the environmental vectors and the

265 ordination coordinates. For the two-way pMANOVA model (habitat and region as predictors), F-

266 statistics were estimated from 1000 permutations of the Bray-Curtis distance matrix using the

267 adonis function in the R library vegan.

268 We tested for significant relationships between environmental (edaphic: soil $\mathrm{pH}$,

269 moisture, organic matter, bulk density; vegetation: [basal area conifer and deciduous?]) variables

270 and the predictors of region and habitat using general linear models (least squares estimation

271 method) (function $\operatorname{lm}$ in R).

272

273 Results

275 Earthworm richness and biomass

276 A total of 806 earthworms from nine species and 5 genera (Dendrobaena, Dendrodrilus,

277 Aporrectodea, Octolasion, Lumbricus) were collected in our study (Tables 3 and 4). Two

278 specimens of unknown and unidentifiable species were not included in the analyses. The highest

279 number of earthworm species was found in Halton Region (Table 3). Aporrectodea rosea, $A$.

280 tuberculata, Octolasion sp., and Lumbricus terrestris were absent from Simcoe County samples, 
281 whereas A. rosea and A. turgida were not found in York County. Dendrobaena octaedra and

282 Dendrodrilus rubidus were absent in Wellington County samples and D. rubidus absent in

283 Halton Region. All nine species were collected with our sampling system in the Deciduous

284 Forests, and Aporrectodea trapezoides was found only in Deciduous Forests (2 specimens)

285 (Table 4). Meadows held the lowest species richness among the studied habitat types, where only

286 A. tuberculata, A. turgida, Octolasion sp. and L. rubellus were collected. Earthworms sampled in

287 the most southerly sites of Halton Region comprised 58\% of the total number of earthworms

288 collected; York, Wellington, and Simcoe Regions represented 21\%, 16\% and 5\% of the total,

289 respectively (Table 3). Throughout the four regions, the total density of earthworms was the

290 highest in the Deciduous Forests (50\%), followed by the Mixed Forests (32\%), the Plantation

291 Forests (15\%), and finally the Meadows (3\%) (Table 4).

292 Earthworm biomass ranged from 0 to $47 \mathrm{~g} \mathrm{per}^{2}$ ( 0 to 153 individuals per $\left.\mathrm{m}^{2}\right)$ in the

293 samples. The general linear model showed that total earthworm biomass decreased with

294 increasing latitude $\left(\mathrm{F}_{1,11}=6.60 ; \mathrm{p}=0.026\right)$ (Fig. 2$)$, indicating regional differences in biomass with

295 the highest being in Halton Region followed by Wellington, York, and Simcoe Regions.

296 Permutation tests on each earthworm genus indicated that the biomass of Lumbricus $(\mathrm{p}=0.036)$

297 and Octolasion ( $\mathrm{p}=0.044)$ genera both decreased with increasing latitude, but there was no

298 relationship between the biomass of either Dendrobaena or Aporrectodea with latitude

299 ( $\mathrm{p}>0.050)$. Neither total earthworm biomass, nor the biomass of a particular genus, differed

300 significantly among the four habitats $(\mathrm{p}>0.050)$.

302 Earthworm community composition 
304 grouped similarly by region (Final stress $=0.06$; probability of achieving observed stress through

305 randomization $=0.04$ ). Sites in the Simcoe and York Regions grouped at the left of the biplot

306 (upper and lower part, respectively) while those from Wellington and Halton Regions grouped

307 together on the right of the biplot. The ordination coordinates for the samples were significantly

308 associated with region and soil $\mathrm{pH}(\mathrm{p}<0.050)$. Dendrodrilus rubidus and Dendrobaena

309 octaedra were associated with Simcoe and York Regions, respectively, whereas Lumbricus sp

310 and Aporrectodea turgida were associated with the southern regions. The pMANOVA indicated

311 that the species composition in the earthworm assemblages differed among regions $\left(\mathrm{F}_{3,5}=3.05\right.$,

$312 \mathrm{p}=0.020)$ but not among habitats $\left(\mathrm{F}_{2,5}=0.82, \mathrm{p}=0.640\right)$. Pairwise comparisons showed that

313 assemblage composition differed between the northernmost Simcoe Region and the two

314 southerly regions, Wellington and Halton $(\mathrm{p}<0.050)$. Differences in functional groups were not

315 clear between habitat types. Mixed Forests and Plantation Forests had the highest density of

316 epigeic earthworm species, which were absent from in the Meadow samples (Table 4). Both

317 endogeic earthworms and the Lumbricus group were most abundant in Deciduous Forest and

318 Mixed Forest types.

\section{Regional and habitat variations in soil}

The general linear models indicated that latitude was associated with differences in soil

322 characteristics such as $\mathrm{pH}$, gravimetric soil moisture, organic matter, and proportion of two size

323 classes of sand. Soil $\mathrm{pH}$, proportion of organic matter, and percentage moisture all decreased

324 with increasing latitude, from Simcoe to Halton Region (Table 5). The linear models indicated 
325 that $\mathrm{pH}$ decreased by 1.1 units with each (decimal) unit of latitude $\left(\mathrm{F}_{1,11}=40.6 ; \mathrm{p}<0.001\right)$, ranging

326 from average value of 6.8 in the southern Wellington and Halton Regions, to 5.7 in the

327 northernmost region, Simcoe. Organic matter decreased by $6 \%$ with each unit of latitude

$328\left(\mathrm{~F}_{1,11}=8.4 ; \mathrm{p}=0.014\right)$, ranging from $12-14 \%$ in Wellington and Halton Regions to $7 \%$ in Simcoe

329 Region. Soil moisture decreased by $22 \%$ with each unit of latitude $\left(F_{1,11}=15.2 ; p=0.002\right)$, ranging

330 from $37-44 \%$ in Wellington and Halton Regions to $16 \%$ in Simcoe Region. Habitat types were

331 less associated with differences in soil characteristics than latitude. Only soil pH varied

332 significantly across all habitats $\left(\mathrm{F}_{3,11}=6.2, \mathrm{p}=0.010\right)$, and pairwise tests indicated that Meadows

333 were significantly drier than Mixed Forests $(\mathrm{p}<0.050)$.

\section{Discussion}

Nine of the 17 known species of exotic earthworms in Ontario were collected in this

337 regional study across south-central Ontario, representing the most common species known to be

338 established in the province (Addison 2009). This is the first study since Reynold's (1977) to

339 examine specific site and habitat information for earthworm assemblages across regions in south-

340 central Canada.

Earthworm biomass varied significantly among the four municipal regions we studied,

342 and this was correlated with soil characteristics. As expected based on visible signs of invasion

343 (patches of missing leaf litter and earthworm middens, casts, and burrow entrances from Suárez

344 et al. 2006a), the southern Halton Region had the highest richness, total biomass, and density of

345 earthworms, followed in decreasing order by Wellington, York, and Simcoe Regions for biomass

346 and density. In contrast, the opposite pattern was seen when only epigeic species were 
347 considered, with the more northerly Simcoe and York Regions having the highest densities of

348 this functional group. Although there are inherent differences in the ecological function of

349 various epigeic species such as between L. rubellus and D. octaedra, we expected that epigeic

350 species in general would be more dominant in sites with sandier soils since work by others has

351 shown a relationship between their abundance and litter depth (McLean and Parkinson 1997),

352 especially in sites where earthworms had been introduced more recently (Hale et al. 2005). In

353 northwestern Canada, Cameron et al. (2007) found that epigeic species such as D. octaedra were

354 more abundant in areas with deeper litter, but they considered this result might be due to

355 unexplained environmental factors such as time since invasion.

Soil characteristics, litter quality, and litter quantity are known to influence earthworm

357 abundance and composition. Increased deciduous regeneration provides litter for many

358 earthworm species, but this is not equally palatable to all. The Plantation Forests in Wellington

359 Region contained saplings of only one tree species whereas those in Halton Region had up to 10

360 species of deciduous tree saplings. In our study, the number of palatable tree species affecting

361 leaf litter, soil $\mathrm{pH}$, and temperature all decreased from south to north, and this would likely slow

362 the rate of earthworm invasion and changes in the forest (Addison 2009) and help explain the

363 differences we observed in Simcoe Region, where the lowest density of earthworms was found

364 together with the lowest soil $\mathrm{pH}$, moisture, and organic matter. In laboratory studies, L. terrestris

365 biomass and growth was greatest at $20^{\circ} \mathrm{C}$ and $30 \%$ soil moisture and reproductive structures

366 developed slower at cooler temperatures (Berry and Jordan 2001). Moreover, York and Simcoe

367 Regions both had high amounts of fine and coarse sand respectively, which corresponded with

368 low earthworm densities. In the national forests of Minnesota and Wisconsin (USA), Holdsworth

369 et al. (2007b) also found increased sandiness to be correlated with decreased earthworm 
370 abundance. Thus, it is not surprising that we found epigeic species to be in higher proportion in

371 the two northerly regions as they appear to tolerate lower $\mathrm{pH}$ and more sandy sites.

372 The low density and biomass of earthworms in the most northerly regions of our study

373 could also possibly be explained by the differential rate of invasion over this latitudinal gradient,

374 with the northern sites likely being invaded more recently than the southern ones. According to

375 Hale et al. (2005), newly invaded areas would be expected to have a higher abundance of epigeic

376 species compared to anecic and endogeic species, and this is consistent with what we observed in

377 the northern Simcoe Region where there was a high proportion of epigeic and Lumbricus species

378 but a small proportion of endogeic species. In addition, because L. terrestris adults were not

379 found in this region, it is likely that the Lumbricus component (adults and immatures) was

380 largely composed of the epi-endogeic species L. rubellus, which is also capable of tolerating low

$381 \mathrm{pH}$ and functions similarly to the other two epigeic species found. In contrast, the most southern

382 regions of Halton and Wellington both had very low densities of epigeics and were dominated by

383 endogeic species. The epigeic species that we saw in the northern regions, Dendrobaena

384 octaedra and D. rubidus, were not found in the two southerly regions, while $A$. rosea was not

385 found in the northerly regions. The lack of Octolasion species and L. terrestris in the northern

386 Simcoe Region was somewhat surprising given that it was in close proximity to large bodies of

387 water where frequent introductions of these species would be thought to occur from sport

388 fishing. Lumbricus terrestris has a relatively slow rate of spread among the species considered

389 here, so its absence in the north could be explained if the original introduction was in the

390 southern sites. Although these variations in functional group composition and earthworm

391 abundance are consistent with predictions from the theory of invasion succession (Hale et al. 
392 2005), there may also be other factors, especially habitat, soil characteristics, and the relatively

393 low sample size that contribute to the observed patterns and must also be considered.

394 In contrast to our predictions, earthworm biomass and the species assemblage

395 composition did not differ significantly among the four habitat types. Based on soil $\mathrm{pH}$, it was

396 predicted that the Plantation Forests would have the highest proportion of epigeic species,

397 followed by the Mixed Forests and Deciduous Forests. Epigeic species were not expected to be

398 abundant in the Meadow sites because the litter layer there would have been reduced by regular

399 agricultural tilling, leaving them unsuitable for earthworm habitat (Nuutinen et al. 1998).

400 Plantation Forests had five times fewer Lumbricus species than endogeic species, which was

401 surprising because endogeic species are not usually found in forest plantations whereas $L$.

402 rubellus is an acid-tolerant species frequently collected from them (Ammer et al. 2006). The

403 relatively high $\mathrm{pH}$ of the Plantation Forest sites, especially in the more southerly regions (Table

404 5), might account for this unexpected result, while the relatively high bulk density of the

405 Meadow sites might account for the low overall abundance of earthworms found there. Smetak

406 et al. (2007) showed that younger urban habitats had increased bulk density due to compaction

407 than more natural habitats, and that this resulted in lower overall earthworm abundance.

408 The stage of succession in the conversion of Plantation Forests to more natural

409 Deciduous Forests potentially had an influence on the earthworm communities we observed in

410 this study. Two of the conifer plantations in the Wellington Region never thinned since being

411 planted in 1982 (M. Neumann 2012, pers. comm.) had no earthworms present whereas the

412 Plantation Forests in Halton Region that had been thinned to promote deciduous regeneration

413 (Gartner Lee Ltd. et al. 2002) averaged 7.38 earthworms per $\mathrm{m}^{-2}$. Thus, variations in forest 
414 management history and practices between the different regions are important in helping to

415 explain local earthworm abundance and assemblages.

416 Based on the general lack of historical information for the timing of earthworm invasion

417 in our study areas, it is difficult to determine definitively the cause of variation in their

418 earthworm communities across the four regions. We do know that the southern sites were settled

419 for agriculture slightly earlier (e.g. late 1700 s to early 1800 s) than the northern sites (e.g. late

4201800 s to early 1900s). In addition, agricultural activities have tended to be more intensive in the

421 southern than in the northern regions, and past land use and management have likely had a

422 profound influence on any associated soil characteristics. Thus, it is likely that our results

423 identify the presence of a latitudinal gradient in earthworm invasion for this region as soil

424 variables were well within the range for survival and likely had little effect on historical

425 movement and introduction patterns. The spread of earthworms is primarily anthropochorous,

426 and species distributions in forests differ depending on the type of human activity (e.g.,

427 settlement, roads, fishing) and land-use history (e.g., Bohlen et al. 2004; Gundale et al. 2005;

428 Cameron et al. 2007; Cameron and Bayne 2009; Sackett et al. 2012). Human population

429 estimates in the northern region were $92 / \mathrm{km}^{2}$ whereas those in the southern region averaged

$430550 / \mathrm{km}^{2}$ (Statistics Canada 2011) supporting the likelihood that human density is an important

431 explanatory variable for differences in the earthworm communities we observed here, and this

432 suggests further investigation is warranted into the effects of human settlement. Our results

433 provide new baseline information on the status, distribution, and relationship of functional

434 earthworm communities with respect to habitat characteristics in south-central Ontario. Armed

435 with this improved understanding, forest managers will be better able to plan for these soil

436 invaders as they continue to advance throughout Canada's forests. 


\section{Acknowledgements}

Funding was provided by the Faculty of Forestry at the University of Toronto, National

440 Science and Engineering Research Council of Canada (NSERC), and the Haliburton Forest \&

441 Wildlife Reserve Inc.. Special thanks to staff in Simcoe County, York Region, Halton Region, 442 City of Guelph, and the Grand River Conservation Authority for forest access.

\section{References}

446 Addison, J.A. 2009. Distribution and impacts of invasive earthworms in Canadian forest

447 ecosystems. Biological Invasions 11: 59-79.

448 Alban, D.H., and Berry, E.C. 1994. Effects of earthworm invasion on morphology, carbon and 449 nitrogen of a forest soil. Appl. Soil Ecol. 1: 243-249.

450 Ammer, S., Weber, K., Abs, C., Ammer, C., and Prietzel, J. 2006. Factors influencing the 451 distribution and abundance of earthworm communities in pure and converted Scots pine $452 \quad$ stands. Appl. Soil Ecol. 33: 10-21.

453 Anderson, M.J. 2001. A new method for non-parametric multivariate analysis of variance.

454 Austral Ecol. 26: 32-46.

455 Berry, E., and Jordan, D. 2001. Temperature and soil moisture content effects on the growth of 456 Lumbricus terrestris (Oligochaeta: Lumbricidae) under laboratory conditions. Soil Biol.

457 Biochem 33: 133-136. 
458 Bohlen, P.J., Groffman, P.M., Fahey, T.J., Fisk, M.C., Suárez, E., Pelletier, D.M., and Fahey,

459 R.T. 2004. Ecosystem consequences of exotic earthworm invasion of north temperate forests.

$460 \quad$ Ecosystems 7: 1-12.

461 Callaham, M.A., González, G., Hale, C.M., Heneghan, L., Lachnicht, S.L., and Zou, X. 2006.

462 Policy and management responses to earthworm invasions in North America. Biological

$463 \quad$ Invasions 8: 1317-1329.

464 Cameron, E.K., and Bayne, E.M.. 2009. Road age and its importance in earthworm invasion of 465 northern boreal forests. J. Appl. Ecol. 46: 28-36.

466 Cameron, E.K., Bayne, E.M., and Clapperton, M.J. 2007. Human-facilitated invasion of exotic 467 earthworms into northern boreal forests. Ecoscience 14: 482-490.

468 Capowiez, Y., Sammartino, S., Michel, E. 2014. Burrow systems of endogeic earthworms:

469 Effects of earthworm abundance and consequences for soil water infiltration. Pedobiologia $470 \quad$ 57: $303-309$.

471 Coja, T., Zehetner, K., Bruckner, A., Watzinger, A., and Meyer, E. 2008. Efficacy and side 472 effects of five sampling methods for soil earthworms (Annelida, Lumbricidae). Ecotoxicol. $473 \quad$ Environ. Safety 71: 552-565.

474 Costello, D.M. and Lamberti, G.A. 2009. Biological and physical effects of non-native 475 earthworms on nitrogren cycling in riparian soils. Soil Biol. Biochem. 41: 2230-2235. 476 Craven, D., Thakur, M.P., Cameron, E.K. et al. 2016.The unseen invaders: Introduced 477 earthworms as drivers of change in plant communities in North American forests (a meta478 analysis). Global Change Biology, in press 
479 Crumsey, J.M, Le Moine, J.M., Capowiez, Y., Goodsitt, M.M., Larson, S.C., Kling, G.W., and 480 Nadelhoffer, K.J. 2013. Community-specific impacts of exotic earthworm invasions on soil 481 carbon dynamics in a sandy temperate forest. Ecology 94: 2827-2837.

482 Denholm, K.A., Schut, L., and D. Irvine. 1993. Field manual for describing soils in Ontario. 483 Ontario Centre for Soil Resource Evaluation, Ontario, Canada, 62 p.

484 Ewing, H., Tuininga, A., Groffman, P. et al. 2015. Earthworms reduce biotic 15-Nitrogen 485 retention in northern hardwood forests. Ecosystems 18: 328-342.

486 Frelich, L.E., Hale, C.M., Scheu, S., Holdsworth, A.R., Heneghan, L., Bohlen, P.J., Reich, P.B. 487 2006. Earthworm invasion into previously earthworm-free temperate and boreal forests.

488 Biological Invasions 8: 1235-1245.

489 Gartner Lee Ltd., Silv-Econ, and TSH Associates. 2002. Profile of Halton Forests (GLL 21-167). $490 \quad$ Page 175.

491 Gates, G.E. 1982. Farewell to North American megadriles. Megadrilogica 4: 12-77.

492 Gundale, M.J., Jolly, W.M., and Deluca, T.H. 2005. Susceptibility of a northern hardwood forest 493 to exotic earthworm invasion. Conserv. Biol. 19: 1075-1083.

494 Hale, C.M., Frelich, L.E., Reich, P.B., and Pastor, J. 2005. Effects of European earthworm 495 invasion on soil characteristics in northern hardwood forests of Minnesota, USA. Ecosystems 496 8: 911-927.

497 Hale, C.M., Frelich, L.E., Reich, P.B., and Pastor, J. 2008. Exotic earthworm effects on 498 hardwood forest floor, nutrient availability and native plants: A mesocosm study. Oecologia 499 155: 509-518. 
500 Hendershot, W.H., Lalande, H., and Duquette, M. 2008. Soil reaction and exchangeable acidity.

501 In Soil Sampling and Methods of Analysis (2nd edition). Edited by Carter, M.R. and E.G.

502 Gregorich, CRC Press, Boca Raton, FL, pp. 173-178.

503 Holdsworth, A.R., Frelich, L.E., and Reich, P.B. 2007a. Regional extent of an ecosystem

504 engineer: Earthworm invasion in northern hardwood forests. Ecological Applications 17:

$505 \quad 1666-1677$.

506 Holdsworth, A.R., Frelich, L.E., and Reich, P.B. 2007b. Effects of earthworm invasion on plant

507 species richness in northern hardwood forests. Conserv. Biol. 21: 997-1008.

508 Jayasinghe, B.A.T.D., and Parkinson, D. 2009. Earthworms as the vectors of actinomycetes

509 antagonistic to litter decomposer fungi. Appl. Soil Ecol. 43: 1-10.

510 Kroetsch, D. and Wang, C. 2008. Particle size distribution. In Soil Sampling and Methods of 511 Analysis (2nd edition). Edited by Carter, M.R. and E.G. Gregorich, CRC Press, Boca Raton, $512 \quad$ FL, pp. 713-725.

513 Lawrence, A.P. and Bowers, M.A. 2002. A test of the "hot" mustard extraction method of

514 sampling earthworms. Soil Biol. \& Biochem. 34: 549-552.

515 Lee, H.T., Bakowsky, W.D., Riley, J., Bowles, J., Puddister, M., Uhlig, P., and McMurray, S.

516 1998. Ecological Land Classification for Southern Ontario: First Approximation and its

517 Application. Ontario Ministry of Natural Resources, Southcentral Science Section, Science

518 Development and Transfer Branch. SCSS Field Guide FG-02.

519 McArdle, B.H., and Anderson, M.J. 2001. Fitting multivariate models to community data: A

520 comment on distance-based redundancy analysis. Ecology 82: 290-297. 
521 McLean, M.A., and Parkinson, D. 1997. Changes in structure, organic matter and microbial 522 activity in pine forest floor following the introduction of Dendrobaena octaedra (Oligochaeta,

523 Lumbricidae). Soil Biol. Biochem. 29: 537-540

524 Migge-Kleian, S., McLean, M.A., Maerz, J.C., and Heneghan,L. 2006. The influence of invasive 525 earthworms on indigenous fauna in ecosystems previously uninhabited by earthworms.

526 Biological Invasions 8: 1275-1285.

527 Nuutinen, V., Pitkänen, J., Kuusela, E., Widbom, T., and Lohilahti, H. 1998. Spatial variation of 528 an earthworm community related to soil properties and yield in a grass-clover field. Appl. Soil 529 Ecol. 8: 85-94.

530 Ontario Ministry of Natural Resources. 2004. Ontario Tree Marking Guide, Version 1.1. Ont. 531 Min. Nat. Resour. Queen's Printer for Ontario. Toronto. 252p.

532 Reynolds, J.W. 1977. The Earthworms (Lumbricidae and Sparganophilidae) of Ontario. Royal 533 Ontario Museum Toronto, Ontario.

534 Reynolds, J.W. 1994. The distribution of the earthworms (Oligochaeta) of Indiana: A case for 535 the post quaternary introduction theory of megadrile migration in North America.

$536 \quad$ Megadrilogica 5: 13-32.

537 Sackett, T., Smith, S.M., and Basiliko, N. 2012. Exotic earthworm distribution in a mixed-use 538 northern temperate forest region: influence of disturbance type, development age, and soils. 539 Can. J. For. Res. 42: 375-381.

540 Sackett, T.E., Smith, S.M., and Basiliko, N. 2013. Indirect and direct effects of exotic 541 earthworms on soil nutrient and carbon pools in North American temperate forests. Soil Biol. $542 \quad$ Biochem. 57: 459-467. 
543 Smetak, K., Johnson-Maynard, J., and Lloyd, J. 2007. Earthworm population density and 544 diversity in different-aged urban systems. Appl. Soil Ecol. 37: 161-168.

545 Smith, R.G., McSwiney, C.P., Grandy, A.S., Suwanwaree, P., Snider, R.M., and Robertson, G.P.

546 2008. Diversity and abundance of earthworms across an agricultural land-use intensity 547 gradient. Soil and Tillage Res. 100: 83-88.

548 Statistics Canada. 2011. Population and Dwelling Count Highlight Tables, 2011 Census.

549 Available from http://www12.statcan.gc.ca/census-recensement/2011/dp-pd/hlt-fst/pd-

$550 \quad$ pl/Table-Tableau.cfm?LANG=Eng\&T $=701 \& S=3$ [accessed 9 January 2017]

551 Suárez, E.R., Fahey, T.J., Groffman, P.M., Yavitt, J.B., and Bohlen, P.J. 2006a. Spatial and

552 temporal dynamics of exotic earthworm communities along invasion fronts in a temperate

553 hardwood forest in south-central New York (USA). Biological Invasions 8: 553-564.

554 Suárez, E.R., Tierney, G.L., Fahey, T.J., and Fahey, R. 2006b. Exploring patterns of exotic

555 earthworm distribution in a temperate hardwood forest in south-central New York, USA.

$556 \quad$ Land. Ecol. 21: 297-306.

557 Szlavecz, K., McCormick, M., Xia, L., Saunders, J., Morcol, T., Whigham, D., Filley, T., and

558 Csuzdi, C. 2011. Ecosystem effects of non-native earthworms in mid-Atlantic deciduous

559 forests. Biological Invasions 13: 1165-1182.

560 Tiunov, A.V., Hale, C.M., Holdsworth, A.R., and Vsevolodova-Perel, T.S. 2006. Invasion

561 patterns of Lumbricidae into the previously earthworm-free areas of northeastern Europe and

562 the western Great Lakes region of North America. Biological Invasions 8: 1223-1234.

563 Zaborski, E. R. 2003.Allylisothiocyanate: An alternative chemical expellant for sampling

564 earthworms. Appl. Soil Ecol. 22: 87-95. 
567 Table 1 -Location, soil order, precipitation, and temperature (1982-2012) of the four study

568 regions in south-central Ontario where earthworm populations were sampled in 2011.

\begin{tabular}{|c|c|c|c|c|}
\hline Region & $\begin{array}{l}\text { Latitudinal range } \\
\left({ }^{\circ} \mathrm{N}\right)\end{array}$ & Soil order(s) & $\begin{array}{l}\text { Average } \\
\text { annual } \\
\text { precipitation } \\
(\mathrm{mm})\end{array}$ & $\begin{array}{l}\text { Average } \\
\text { annual } \\
\text { temperature } \\
\left({ }^{\circ} \mathrm{C}\right)\end{array}$ \\
\hline Simcoe & $44.49-44.60$ & Podzols & 938 & 6.6 \\
\hline York & $44.04-44.10$ & Grey brown Podzols & 857 & 7.4 \\
\hline Wellington & $43.50-43.54$ & Podzols and gleysols & 905 & 6.6 \\
\hline Halton & $43.46-43.56$ & Gleysols, luvisols, brunisols & 884 & 6.8 \\
\hline
\end{tabular}


577 Table 2. Location and characteristics of the 31 study sites in south-central Ontario, Canada where 578 earthworm populations were sampled in 2011.

\begin{tabular}{|c|c|c|c|c|c|}
\hline \multirow{2}{*}{$\begin{array}{l}\text { Habitat } \\
\text { Site code }\end{array}$} & \multirow[t]{2}{*}{ Dominant species $^{\mathrm{a}}$} & \multirow{2}{*}{$\begin{array}{c}\text { Age } \\
\text { (years) }\end{array}$} & \multirow{2}{*}{$\begin{array}{l}\text { Previous land } \\
\text { use }\end{array}$} & \multicolumn{2}{|c|}{ Centroid location $^{b}$} \\
\hline & & & & Northing & Easting \\
\hline \multicolumn{6}{|l|}{ Deciduous } \\
\hline SCDFA & $\operatorname{Mh}(57 \%)$, Aw $(1 \%)$ & 99 & Natural & 44.4943 & -79.8148 \\
\hline SCDFB & $\operatorname{Mh}(91 \%)$ & 107 & Natural & 44.5927 & -79.7997 \\
\hline YRDFA & $\operatorname{Mh}(60 \%), \operatorname{Aw}(19 \%)$ & 80 & Natural & 44.0460 & -79.3227 \\
\hline YRDFB & $\operatorname{Mh}(55 \%)$ & 102 & Natural & 44.0682 & -79.2864 \\
\hline CGDFA & $\operatorname{Ag}(53 \%), \operatorname{Msi}(31 \%)$ & $>40$ & Agriculture & 43.5249 & -80.3005 \\
\hline CGDFB & $\operatorname{Ag}(48 \%), \operatorname{Msi}(48 \%)$ & $>40$ & Agriculture & 43.5358 & -80.2914 \\
\hline HRDFA & $\operatorname{Mh}(82 \%)$ & 65 & Pasture & 43.5403 & -79.9865 \\
\hline HRDFB & $\operatorname{Mh}(52 \%)$ & 75 & Agriculture & 43.5112 & -79.9960 \\
\hline \multicolumn{6}{|l|}{ Mixed } \\
\hline SCMFA & $\operatorname{He}(39 \%), \operatorname{Mh}(29 \%)$ & 80 & Natural & 44.4965 & -79.8137 \\
\hline SCMFB & $\operatorname{Mh}(48 \%), \mathrm{He}(36 \%)$ & 98 & Natural & 44.5935 & -79.8002 \\
\hline YRMFA & $\operatorname{He}(51 \%), \operatorname{Mh}(19 \%)$ & 132 & Natural & 44.0706 & -79.2836 \\
\hline YRMFB & $\mathrm{He}(50 \%), \mathrm{Mh}(18 \%)$ & 132 & Natural & 44.0704 & -79.2819 \\
\hline CGMFA & $\operatorname{He}(30 \%), \operatorname{Ag}(28 \%)$ & $>40$ & Agriculture & 43.5102 & -80.2209 \\
\hline CGMFB & $\operatorname{Ag}(33 \%), \operatorname{He}(17 \%)$ & $>40$ & Agriculture & 43.5107 & -80.2218 \\
\hline HRMFA & $\mathrm{Mh}(25 \%), \mathrm{He}(14 \%)$ & 57 & Forestry & 43.5320 & -80.0940 \\
\hline HRMFB & $\mathrm{Pw}(23 \%), \mathrm{Bw} 19 \%)$ & 75 & Agriculture & 43.4632 & -79.9934 \\
\hline \multicolumn{6}{|l|}{ Plantation } \\
\hline SCPPA & $\operatorname{Pr}(67 \%)$ & 52 & Agriculture & 44.4937 & -79.8096 \\
\hline SCPPB & $\operatorname{Pr}(86 \%)$ & 71 & Agriculture & 44.6054 & -79.7865 \\
\hline YRPPA & $\operatorname{Pr}(81 \%)$ & 53 & Cleared (unk) ${ }^{\mathrm{d}}$ & 44.0877 & -79.3596 \\
\hline YRPPB & $\operatorname{Pr}(85 \%)$ & 55 & Cleared (unk) ${ }^{\mathrm{d}}$ & 44.0428 & -79.3209 \\
\hline CGPPA & $\mathrm{Pw}(100 \%)$ & 30 & Agriculture & 43.5028 & -80.2009 \\
\hline CGPPB & Pw $(100 \%)$ & 30 & Agriculture & 43.5037 & -80.2049 \\
\hline HRPPA & $\mathrm{Sw}(48 \%), \mathrm{Pw}(28 \%)$ & 45 & Agriculture & 43.5203 & -80.0558 \\
\hline HRPPB & $\mathrm{Sw}(48 \%), \operatorname{Pr}(23 \%)$ & 55 & Agriculture & 43.5630 & -80.0166 \\
\hline \multicolumn{6}{|l|}{ Meadow $^{\text {c }}$} \\
\hline SCMA & Solispp, Asclsyri & unknown & Agriculture & 44.5287 & -79.6164 \\
\hline SCMB & Solispp, Asclsyri & unknown & Agriculture & 44.5491 & -79.5953 \\
\hline YRMA & Old crop & unknown & Agriculture & 44.1013 & -79.3388 \\
\hline YRMB & Old crop & unknown & Agriculture & 44.1001 & -79.3394 \\
\hline CGMA & Solispp, Dauccaro & unknown & Agriculture & 43.5039 & -80.2071 \\
\hline CGMB & Solispp, Corovari & unknown & Agriculture & 43.5036 & -80.2276 \\
\hline HRMA & Solispp, Rubuidae & unknown & Agriculture & 43.5024 & -79.9947 \\
\hline \multicolumn{6}{|c|}{$\begin{array}{l}\text { a (\%) Percentage composition of the dominant species based on proportion of total number of trees; See Appendix } 1 \\
\text { for a list of species name and abbreviations. }\end{array}$} \\
\hline $\begin{array}{l}{ }^{b} \text { Centroid loca } \\
\text { toolbox in the } \\
{ }^{c} \text { Dominant veg } \\
\text { dunk = Record }\end{array}$ & $\begin{array}{l}\text { of the five plots was determi } \\
\text { gram ArcMap } 10.0 \text { (ESRI } 201 \\
\text { tion is based on flowering herl }\end{array}$ & $\begin{array}{l}\text { ined using the ' } \mathrm{r} \\
\text { 10). }\end{array}$ & median center' functio & f the spatial st & $\begin{array}{l}\text { stics } \\
\text { es. }\end{array}$ \\
\hline
\end{tabular}


579 Table 3 - Mean densities (and range) of earthworm species collected from the four regions of 580 south-central Ontario, Canada during 2011.

581

\begin{tabular}{|c|c|c|c|c|c|}
\hline \multirow[b]{2}{*}{$\begin{array}{l}\text { Functional } \\
\text { group and } \\
\text { species }\end{array}$} & \multicolumn{5}{|c|}{ Mean density (individuals per $\mathbf{m}^{2}$ ) } \\
\hline & $\begin{array}{c}\text { Simcoe } \\
(n=40)\end{array}$ & $\begin{array}{c}\text { York } \\
(n=40)\end{array}$ & $\begin{array}{c}\text { Wellington } \\
(n=40)\end{array}$ & $\begin{array}{c}\text { Halton } \\
(n=35)\end{array}$ & $\begin{array}{l}\text { Average } \\
\text { density }\end{array}$ \\
\hline \multicolumn{6}{|l|}{ Epigeic } \\
\hline $\begin{array}{l}\text { Dendrobaena } \\
\text { octaedra }\end{array}$ & $0.47(0-3.75)$ & $0.91(0-10.00)$ & 0 & $0.25(0-3.75)$ & $0.41(0-10.00)$ \\
\hline $\begin{array}{l}\text { Dendrodrilus } \\
\text { rubidus }\end{array}$ & $0.06(0-1.25)$ & $0.03(0-1.25)$ & 0 & 0 & $0.02(0-1.25)$ \\
\hline Total epigeic & $0.53(0-5.00)$ & $0.94(0-5.00)$ & 0 & $0.25(0-3.75)$ & $0.43(0-10.00)$ \\
\hline \multicolumn{6}{|l|}{ Endogeic } \\
\hline $\begin{array}{l}\text { Aporrectodea } \\
\text { juveniles }\end{array}$ & $0.06(0-1.25)$ & $0.94(0-5.00)$ & $1.31(0-7.50)$ & $4.82(0-16.25)$ & $1.69(0-16.25)$ \\
\hline A. rosea & 0 & 0 & $0.09(0-1.25)$ & $0.29(0-2.50)$ & $0.09(0-2.50)$ \\
\hline A. trapezoides & $0.06(0-2.50)$ & 0 & 0 & 0 & $0.02(0-2.50)$ \\
\hline A. tuberculata & 0 & $0.5(0-5.00)$ & $0.40(0-5.00)$ & $0.82(0-3.75)$ & $0.42(0-5.00)$ \\
\hline $\begin{array}{l}\text { Aporrectodea } \\
\text { turgida (Eisen) }\end{array}$ & $0.03(0-1.25)$ & 0 & $0.13(0-3.75)$ & $0.86(0-5.00)$ & $0.23(0-5.00)$ \\
\hline $\begin{array}{l}\text { Octolasion } \\
\text { species }\end{array}$ & 0 & $0.75(0-7.50)$ & $1.81(0-22.5)$ & $3.11(0-21.25)$ & $1.36(0-22.50)$ \\
\hline Total endogeic & $0.15(0-2.50)$ & $2.19(0-10.00)$ & $3.74(0-30.00)$ & $9.90(0-32.50)$ & $3.81(0-32.50)$ \\
\hline \multicolumn{6}{|l|}{ Lumbricus group } \\
\hline $\begin{array}{l}\text { Lumbricus } \\
\text { juveniles }\end{array}$ & $0.44(0-8.75)$ & $0.75(0-6.25)$ & $1.5(0-8.75)$ & $5.07(0-25.00)$ & $1.84(0-25.00)$ \\
\hline L. rubellus & $0.06(0-1.25)$ & $0.03(0-1.25)$ & $0.03(0-1.25)$ & $0.68(0-8.75)$ & $0.16(0-8.75)$ \\
\hline L. terrestris & 0 & $0.03(0-1.25)$ & $0.09(0-1.25)$ & $0.64(0-5.00)$ & $0.18(0-5.00)$ \\
\hline $\begin{array}{l}\text { Total } \\
\text { Lumbricus } \\
\text { group }\end{array}$ & $0.50(0-10.00)$ & $0.81(0-6.25)$ & $1.62(0-8.75)$ & $6.39(0-32.50)$ & $2.18(0-32.50)$ \\
\hline $\begin{array}{l}\text { Average density } \\
\text { of all species } \\
\left(\mathrm{m}^{-2}\right)\end{array}$ & $1.18(0-11.25)$ & $3.94(0-13.75)$ & $5.38(0-38.75)$ & $16.54(0-65.0)$ & $6.17(0-65.00)$ \\
\hline $\begin{array}{l}\text { Number of } \\
\text { species }\end{array}$ & 5 & 6 & 5 & 7 & \\
\hline
\end{tabular}


583 Table 4.Mean densities and range of earthworm species collected from the four habitat types in 584 south-central Ontario during 2011.

\begin{tabular}{|c|c|c|c|c|}
\hline \multirow[b]{2}{*}{$\begin{array}{l}\text { Functional group and } \\
\text { species }\end{array}$} & \multicolumn{4}{|c|}{ Mean density (individuals per $\mathbf{m}^{2}$ ) } \\
\hline & $\begin{array}{l}\text { Deciduous forest } \\
\qquad(n=40)\end{array}$ & $\begin{array}{l}\text { Mixed forest } \\
\quad(n=40)\end{array}$ & $\begin{array}{c}\text { Plantation } \\
\text { forest } \\
(\mathbf{n}=\mathbf{4 0})\end{array}$ & $\begin{array}{c}\text { Meadow } \\
(n=35)\end{array}$ \\
\hline \multicolumn{5}{|l|}{ Epigeic } \\
\hline $\begin{array}{l}\text { Dendrobaena } \\
\text { octaedra }\end{array}$ & $0.34(0-3.75)$ & $0.66(0-10.00)$ & $0.59(0-3.75)$ & 0 \\
\hline Dendrodrilus rubidus & $0.03(0-1.25)$ & $0.03(0-1.25)$ & $0.03(0-1.25)$ & 0 \\
\hline Total epigeic & $0.37(0-5.00)$ & $0.69(0-11.25)$ & $0.62(0-5.00)$ & 0 \\
\hline \multicolumn{5}{|l|}{ Endogeic } \\
\hline $\begin{array}{l}\text { Aporrectodea } \\
\text { juveniles }\end{array}$ & $3.16(0-16.25)$ & $1.69(0-6.25)$ & $1.41(0-11.25)$ & $0.32(0-7.50)$ \\
\hline A. rosea & $0.06(0-1.25)$ & $0.16(0-1.25)$ & $0.13(0-2.50)$ & 0 \\
\hline A. trapezoides & $0.06(0-2.50)$ & 0 & 0 & 0 \\
\hline A. tuberculata & $0.28(0-3.75)$ & $0.72(0-5.00)$ & $0.59(0-5.00)$ & $0.04(0-1.25)$ \\
\hline A. turgida & $0.59(0-5.00)$ & $0.22(0-2.50)$ & $0.06(0-2.50)$ & $0.04(0-1.25)$ \\
\hline Octolasion species & $2.66(0-21.25)$ & $2.19(0-22.50)$ & $0.31(0-5.00)$ & $0.14(0-2.50)$ \\
\hline Total endogeic & $6.81(0-50.00)$ & $4.98(0-37.50)$ & $2.50(0-26.25)$ & $0.54(0-5.00)$ \\
\hline \multicolumn{5}{|l|}{ Lumbricus group } \\
\hline Lumbricus juveniles & $4.47(0-25.00)$ & $1.94(0-11.25)$ & $0.47(0-2.50)$ & $0.29(0-5.00)$ \\
\hline L. rubellus & $0.63(0-8.75)$ & $0.03(0-1.25)$ & $0.03(0-1.25)$ & $0.04(0-1.25)$ \\
\hline L. terrestris & $0.28(0-2.50)$ & $0.31(0-5.00)$ & $0.09(0-2.50)$ & 0 \\
\hline $\begin{array}{l}\text { Total Lumbricus } \\
\text { group }\end{array}$ & $5.38(36.25)$ & $2.28(0-17.50)$ & $0.59(0-6.25)$ & $0.33(1.75)$ \\
\hline $\begin{array}{l}\text { Average density of all } \\
\text { species }\left(\mathrm{m}^{-2}\right)\end{array}$ & $12.56(0-65.00)$ & $8.00(0-38.75)$ & $3.72(0-22.50)$ & $0.86(0-13.8)$ \\
\hline Number of species & 9 & 8 & 8 & 4 \\
\hline
\end{tabular}


589 Table 5. Mean values of soil variables and statistical variation between regions or habitat types

590 based on the top $10 \mathrm{~cm}$ of soil from the four sites sampled in southern Ontario. GSM:

591 gravimetric soil moisture, OM: organic matter, BD: bulk density

\begin{tabular}{|c|c|c|c|c|c|c|}
\hline & $\mathbf{p H}$ & $\begin{array}{l}\text { GSM } \\
(\%)\end{array}$ & OM (\%) & $\begin{array}{l}\text { BD } \\
\left(\mathrm{g} / \mathrm{cm}^{3}\right)\end{array}$ & $\begin{array}{l}\text { \% fine } \\
\text { sand } \\
(<250 \mu \mathrm{m})\end{array}$ & $\begin{array}{l}\text { \% coarse } \\
\text { sand } \\
(>250 \mu \mathrm{m})\end{array}$ \\
\hline \multicolumn{7}{|l|}{ Region } \\
\hline Simcoe & $5.70 \pm 0.16$ & $16.4 \pm 2.8$ & $7.23 \pm 1.1$ & $0.67 \pm 0.10$ & $43.9 \pm 6.9$ & $50.1 \pm 6.4$ \\
\hline York & $6.41 \pm 0.25$ & $34.0 \pm 4.4$ & $9.35 \pm 1.8$ & $0.69 \pm 0.09$ & $68.5 \pm 5.0$ & $10.1 \pm 5.1$ \\
\hline Wellington & $6.80 \pm 0.10$ & $37.1 \pm 5.0$ & $13.9 \pm 2.2$ & $0.76 \pm 0.03$ & $42.8 \pm 3.0$ & $14.1 \pm 3.6$ \\
\hline Halton & $6.89 \pm 0.09$ & $44.3 \pm 1.8$ & $12.6 \pm 0.9$ & $0.69 \pm 0.02$ & $43.0 \pm 1.9$ & $14.8 \pm 1.1$ \\
\hline \multicolumn{7}{|l|}{ Habitat type } \\
\hline Deciduous & $6.65 \pm 0.16$ & $36.9 \pm 5.3$ & $13.4 \pm 2.1^{1}$ & $0.64 \pm 0.04$ & $41.8 \pm 4.8$ & $31.3 \pm 8.0$ \\
\hline Mixed & $6.03 \pm 0.24$ & $37.0 \pm 5.7$ & $12.5 \pm 1.3$ & $0.53 \pm 0.07$ & $49.8 \pm 6.4$ & $19.4 \pm 8.8$ \\
\hline Plantation & $6.28 \pm 0.26$ & $28.3 \pm 5.3$ & $10.0 \pm 1.3$ & $0.69 \pm 0.03$ & $55.1 \pm 7.6$ & $18.6 \pm 6.6$ \\
\hline Meadow & $6.82 \pm 0.16$ & $27.9 \pm 4.1$ & $6.29 \pm 1.3$ & $0.93 \pm 0.06$ & $51.6 \pm 4.9$ & $20.1 \pm 6.3$ \\
\hline
\end{tabular}




\section{Figure captions}

603

604 Figure 1. Centroid locations of the 31 study sites for the four study regions (shaded in grey) in

605 southern Ontario (shaded). $\odot=$ deciduous forests (DF), $\Delta=$ mixed forests (MF), $\square=$ plantations

606 (PP), +=meadows (M).

607

608 Figure 2. Total earthworm biomass at 15 sites in four different habitat types distributed

609 latitudinally across southern Ontario, Canada. The solid line is the linear regression line and the

610 shaded area is the $95 \%$ confidence region $\left(r^{2}=0.55 ; p=0.048\right)$. Habitat abbreviations are as in

611 Figure 1.

612

613 Figure 3. Ordination (NMDS) plots of earthworm species assemblage composition from 15

614 collections across southern Ontario. Points are individual observations and ellipses enclose 1 SD

615 of the data for samples within the Halton (H), York (Y) and Simcoe (S) Regions. No ellipse is

616 drawn for Wellington (W) Region as only two samples are plotted. Gray arrows indicate the

617 direction of significantly correlated environmental or geographical variables with differences in

618 species composition among sites. Hollow diamonds with species names indicate the relative

619 distribution of species among sites. 
623

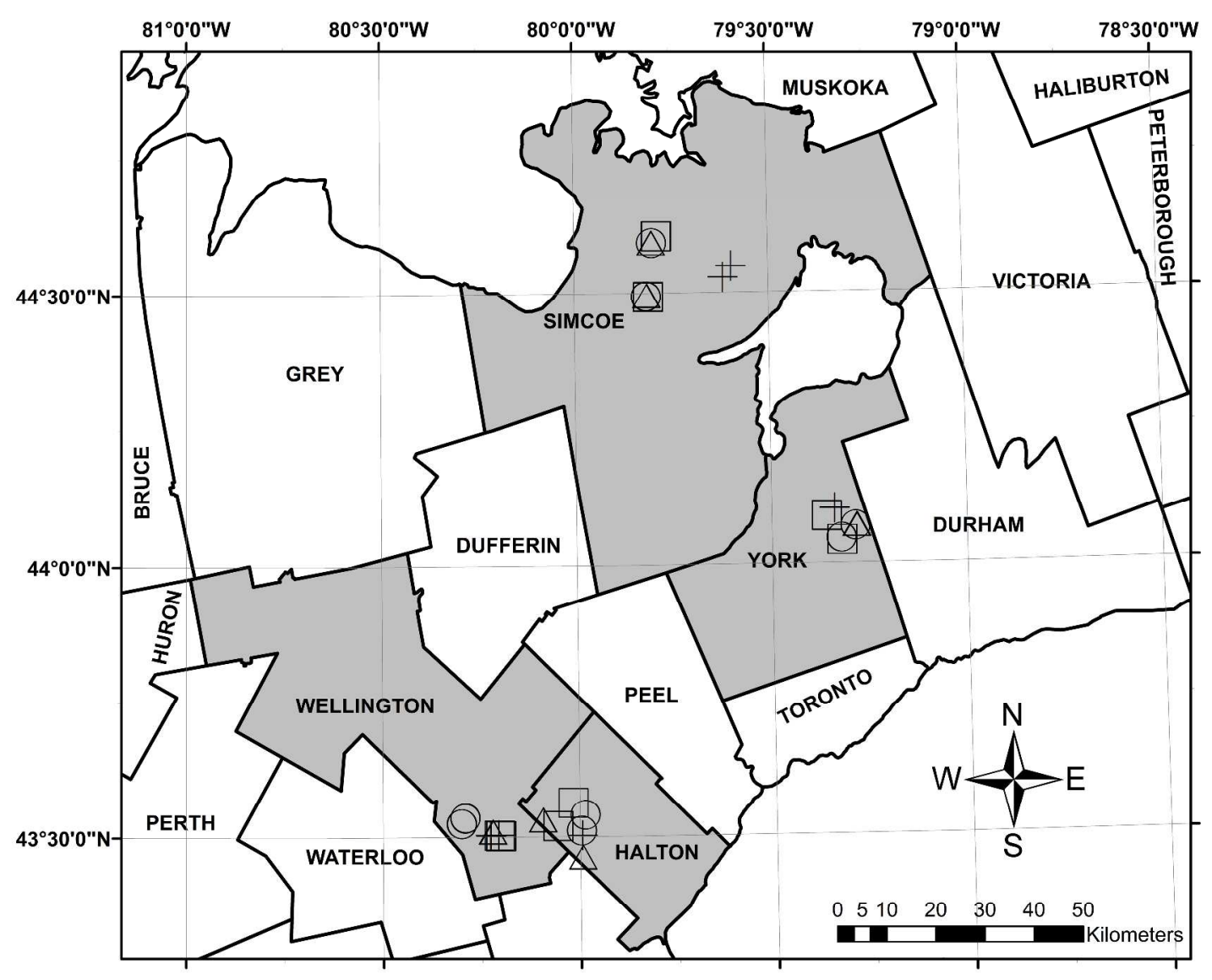

624

625 


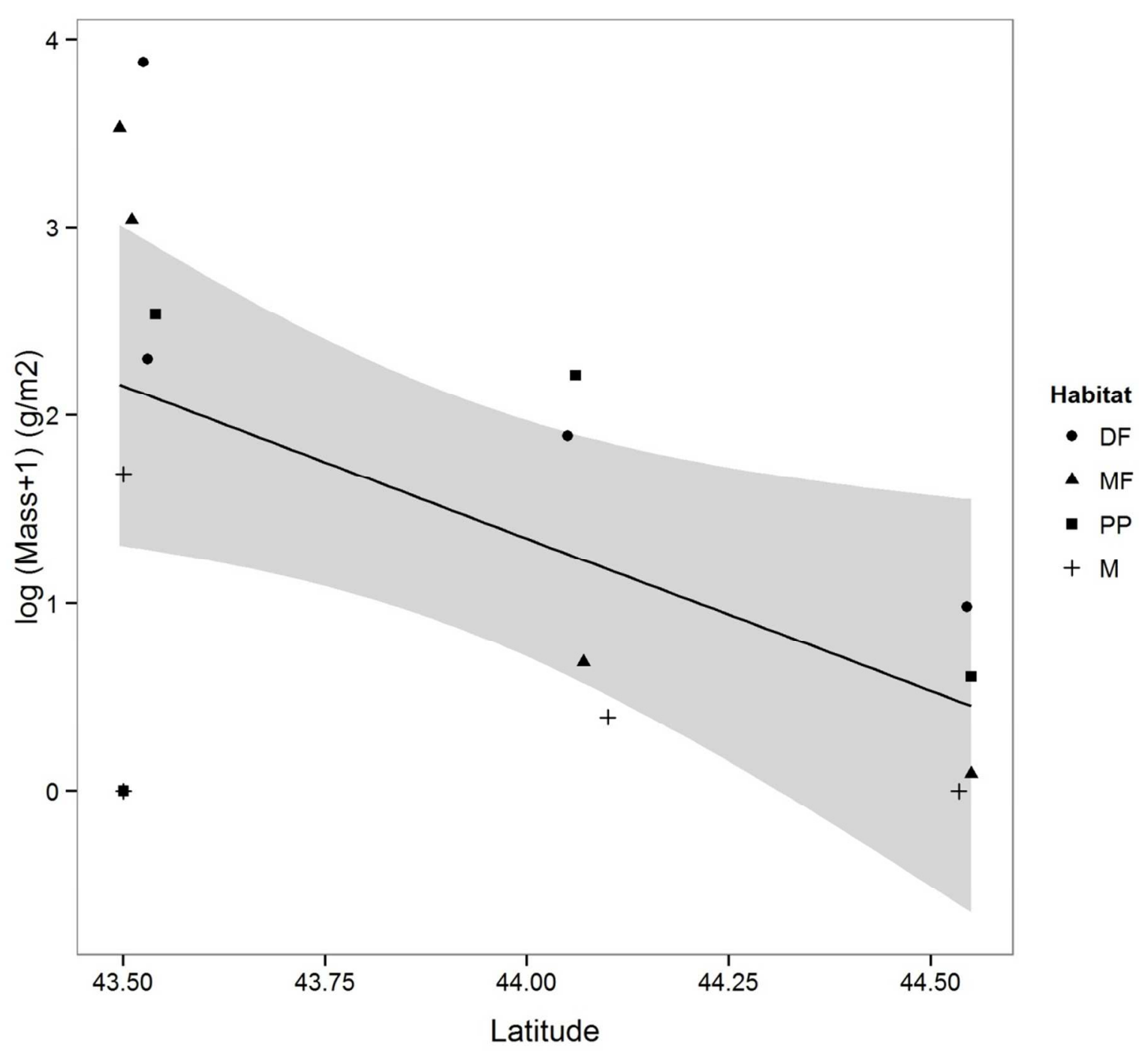

626

627

628

629

630

631

632

633

634

635 


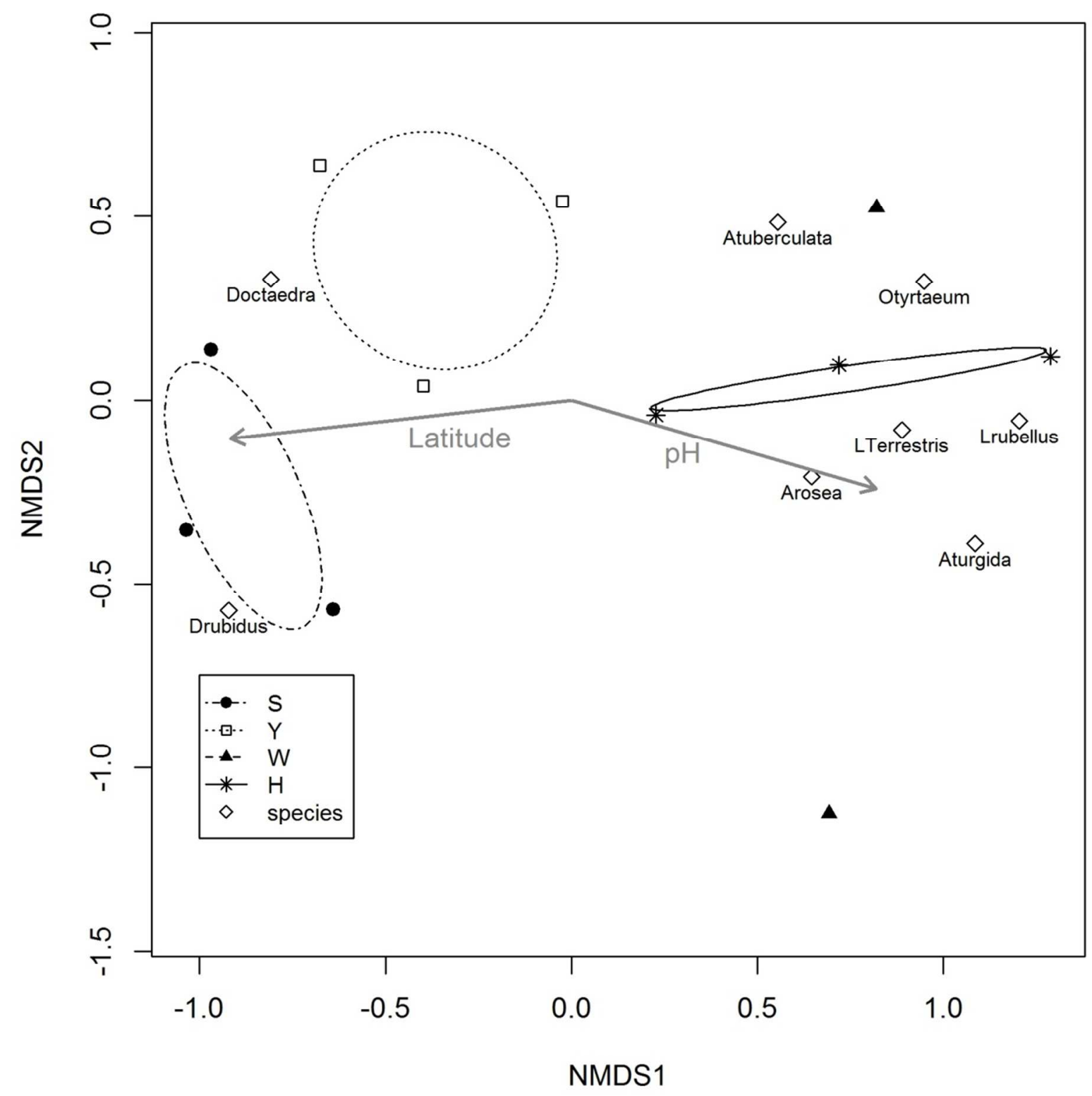

636 